\title{
Business Survivability: Social Media as a Channel in the Pandemic Era
}

\author{
http://dx.doi.org/10.25008/jkiski.v6i1.498
}

\author{
Miftha Pratiwi \\ Department of Communication Science, Universitas Sriwijaya \\ J1. Raya Palembang-Prabumulih Km.32 Indralaya 30662, South Sumatera - Indonesia \\ Corresponding author: mifthapratiwi@fisip.unsri.ac.id
}

Submitted: February 28, 2021, Revised: March 30, 2021, Accepted: May 21, 2021

Accredited by Kemristekdikti No. 28/E/KPT/2019

\begin{abstract}
Almost this past one-year Indonesia has been undergoing global crisis due to COVID-19 pandemic. The weakening of economic sector is caused by the restriction of activity as one form of the supports for the Government in applying health protocol. Many companies of various fields are unable to survive because of undergoing economic contraction. While there are so many companies are having economic contraction, YLEO Indonesia strives. According to one of the distributors, who gains a status as a diamond leader, the income of YLEO increases to $40 \%$ during the pandemic. This success is certainly not apart from the role of strategic communication conducted by the company. Moreover, if the company uses social media as one means or channel of communication in conveying education, promotion and interaction with its audience. This research aims at understanding the utilization of social media as a means of communication adopted which supports the business activity of YLEO. The method employed is qualitative descriptive in the form of in-depth interviews as the data collection technique, and content analysis. The summary of this research is the management and utilization of social media as important parts of the company because they are able to encourage the involvement of the audience in various activities in order to further know and understand the expectation and message relevancy which are conveyed to the audience.
\end{abstract}

Keywords: business survivability; social media; channel; essential oils company; pandemic

\section{Introduction}

The Corona Virus Disease-19 (COVID19) has been a global challenge (Patma et al., 2020). COVID-19 is an unexpected situation because it harms all sectors (Hidayat et al., 2020), and has changed the life of all people economically, socially, and psychologically. Not only killing people, COVID-19 also causes economic paralysis, starting from work termination, the fall in the exchange rate of Indonesian Rupiah towards US Dollar, to the soaring prices of basic necessities (Prayoga, 2020). It is strengthened by the statement of the United Nations Secretary General Antonio Guterres who states that this corona virus pandemic is the worst global crisis since the World War II (Christiastuti, 2020).

According to the statement from Badan Pusat Statistik (Central Bureau of Statistics) that the economic growth in Indonesia in the second quarter of 2020 decreases to $5.32 \%$ (Badan Pusat Statistik, 2020). It indicates that the corona virus has succeeded in ruining Indonesian economy. The Minister of Finance Sri Mulyani states that there are three big economic impacts of COVID-19. First, its impact is on household consumption or the falling of people's buying power. Second, investment is weakening in the middle of COVID-19 pandemic uncertainty. Third, the 
worldwide economic weakening which makes the Indonesian exports terminated (Abidin Achmad et al., 2020). Moreover, since the Government issued the policy on social distancing which is governed by Large-scale Social Restriction, also affecting on business activities (Presiden Republik Indonesia, 2019).

Agung Laksamana, as the Chairman of Perhimpunan Hubungan Masyarakat (Perhumas) in his book titled "Adapt or Die" states that COVID-19 has changed the world. All aspects, including academics, practitioners to entrepreneurs (businesspeople) are forced to adapt immediately during the pandemic. It indicates that in any situation, we need to adapt with the changes if we do not want to be obsolete or even extinct (Laksamana, 2020). As cited from CNN Indonesia site, there are so many global companies declare bankruptcy. Starting from restaurants, clothing and household equipment, oil producer, to airlines, even a 200year-old company is forced to declare bankruptcy due to economic pressure in the middle of the pandemic. This situation actually tests to the mentality and bring challenges for business people and entrepreneurs to strive (CNN Indonesia, 2020).

If we observe the trend of this pandemic, all patterns change. Our activities are done more actively online. Previously, we are used to meet or to do activities in person, but now since the pandemic, we more utilize more a digital platform or social media, one of which is in marketing activity. All entrepreneurs or businesspeople need to think hard and be adaptive to market their product, both goods and services, as branding strategy in the middle of corona virus pandemic. Entrepreneurs or businesspeople optimize online marketing and digital branding as means of communication with their audience (Aryanto, 2020). Social media selection is a smart move (Prayoga, 2020).

Social media in the field of communication is a natural extension. As the most popular communication platform in the digital age, social media have completely transformed the ways companies communicate with consumers, to the extent that they have become key drivers of new marketing and public relations rules (Boon-Long \& Wongsurawat, 2015). Kalpana and Haenlein (2010) defined social media as a group of internet based applications that build on ideological and technological foundation of web 2.0 and allow the creation and exchange of user generation content (Ghoshal, 2019).
The users of social media grow rapidly all over the world, including in Indonesia. For individual, the motivation of using social media is to search for information, various informations, entertainment, relaxation, and social interactions. Based on a survey conducted by Asosiasi Penyelenggara Jasa Internet Indonesia (APJII) or (Indonesian Internet Service Provider Association), internet users in Indonesia become the important part to manifest the digital transformation (APJII, 2020). If combined with the projection figures by BPS, Indonesian population in 2019 is $266,911,900$ so that the internet users in Indonesia in 2020 is estimated as many as 196.7 million users. That figure increases from 171 million in 2019 with $73.7 \%$ penetration or increases as much as $8.9 \%$ equals to 25.5 million users. While the data of social media trend in 2020 in Indonesia according to We Are Social that the internet users who are on social media is as many as 160 million users (We Are Social \& Hootsuite, 2020).

As the most popular communication platform in the modern era, social media provides a very conductive platform to the marketers for connecting with the existing as well as the prospective customers (Mukherjee, 2019). The marketing activity through social media utilization conducted by a brand has a very positive impact on marketing and the company (Kim \& Ko, 2012). The result of the research by Nielsen Digital Consumer 2019 shows that digital consumers indicate a positive growth trend, whereas every day, online shopping activity reaches $67 \%$ especially during work hour (around at 09.00 to 15.00) (Lubis, 2020).

According to Tuten, social media is frequently defined as sites where users can create, publish, control, critique, rank, and interact with online content. Such as blogs, micro-blogs, video sharing, bookmarking applications, wikis, forums, and opinion sites as well as social networks (Papasolomou \& Melanthiou, 2012). There are some social media which are booming nowadays, such as Twitter, Line, Facebook, Instagram, Whatsapp, Youtube, TikTok, et cetera. The founder of Social Media Club and new media innovator, Chrish Heuer, discusses the Four Cs for a social framework: (1) Context, how we frame our stories, (2) Communications, the practice of sharing our story as well as listening, responding, and growing, (3) Collaboration, working together to make things better and more efficient and effective, and (4) 
Connections, the relationships we forge and maintain(Solis, 2011).

In book titled Menciptakan Penjualan melalui Social Media (Creating Sales through Social Media) by Puntoadi says that a way to correctly defines social media is to compare it with the previous generation with web-based 1.0. Social media can do various two-way activities in various exchanges, collaborations, and getting to know each other, both in the form of texts, visual, and audio-visual. Also those things are not found in previous era that is webbased 1.0 media (Rochadi, 2016). Social media has some differences with other marketing communication media, that is always on and everywhere (South, 2011).

One of the advantages of social media is having many potential for business development. Social media can be used to do communication activity in business, help market a product, both goods and services, twoway communication, and directly connected with customer and potential buyers. One of the companies that actively uses social media in their business marketing activity is essential oils company, namely YLEO.

YLEO has been established for 25 years by D. Gary Young and is successfully developed to become world leader in essential oils industry and network marketing. Up to present, YLEO has 26 offices, experience centre, and distribution centre around the world which serves more than 150 countries, one of which is Indonesia (Young Living, 2018).

The interesting thing is that while many companies are unable to survive due to economic contraction, YLEO experiences an increase. Based on the pre-research result conducted on one of the diamond leader, the income of YLEO Indonesia is increased to $40 \%$ during the pandemic. The first reason is the increasing of customer buying interest on YLEO oil product especially related to respiration problems. Moreover since the corona virus situation which urge us to maintain our immunity, one of which is by using an oil product by YLEO. Oil products by YLEO itself is a set of essential oils contain of herb extracts with standard program Seed to Seal, that gives many benefits for health and beauty (Young Living, 2018).

The second reason is that every time we buy the product and become a member of YLEO, it gives us an opportunity to run a business. Cited from the YLEO site, YLEO classifies their members into two categories, they are preferred customers and business builders. Preferred customers are the members who want to give benefits without participating in building the business. While business builders are those who participate in building the YLEO business. As we know that this time Indonesia is undergoing economic crisis because of COVID-19. It can be a good business opportunity, not only for housewives but also for everyone who wants to get more income.

In their business marketing activities, YLEO not only do direct selling but also online. As previously explained, that COVID-19 has succeeded in changing our activity patterns from direct into online by using digital platform or social media. Thus, all of us need to be able to adapt with changes, including the changes of our business activity by online. No wonder that customer online shopping trend is increasing rapidly. It is undeniable that social media has become a very important communication channel in doing business strategy, one of which is social media marketing.

Social Media Marketing is a set of activities for business promotion through social networks. Social media marketing is a quite new thing in the marketing world so there is no fundamental literature on the subject (Zaitseva et al., 2019). So, in this paper, the researcher attempt to find out the importance and the effectiveness of social media as a channel of company to support their business and marketing activities. Most of the existing studies focus on specific issues, such as reviewing all the digital platform (Sundaram, R., Sharma, R., Shakya, 2020), improving brand loyalty (Boon-Long \& Wongsurawat, 2015), evaluation using social network to identifying purchasing decision (Budiatmo \& Kurniasari, 2018), and buying interest (Felix et al., 2017). While these studies more detailing on the progress in specific knowledge on social media in context with communication as a channel used for supporting business marketing activities, the existing literatures do not provide a framework for social media marketing at a strategic level. In a nutshell, research about marketing in social media (social media marketing) need to be re-conceptualized (Evan, 2012).

Ritcher \& Koch state that social media is an applications, a platforms and an online media which aims at facilitating interaction, collaborations, and various contents. Social media is a "complementary" of all marketing efforts in a company. One of the most valuable aspects of social media from a marketer's 
perspective is in building and maintaining a feedback loop (Mangold \& Faulds, 2009). The emergence of internet-based social media has made it possible for one person to communicate with hundreds or even thousands of people about the products and companies that provide them (Zaitseva et al., 2019). Unlike other advertising tools, the internet and social media makes it possible to attract real consumers with a minimum or zero budget (Meilinda, 2018).

\section{Theoretical Framework}

To many people, social media is many things and represents much more than technology. It represents a societal renaissance that has resulted in a distinct and vibrant ecosystem supported by thriving cultures and lifestyles. Social media is (1) a platform for the socialization of media; (2) the online tools that facilitate conversations; (3) connections between friends, peers, and influencers; (4) collaborations; (5) the redistribution of influence; (6) a call for humanizing personas and audiences, and the stories that link them together; (7) compassionate; (8) words, pictures, video, chatter, audio, and also experiences, observations, opinions, news, and insights; also (9) an opportunity and a privilege (Solis, 2011)

If we established a basic concept, social media is based on natural, genuine conversation between people about something of mutual interest, and that, as applied to business, that conversation is relevant to a specific marketplace. Because social media gains its power from sharing and consensus, if you influence it by any means other than transparent, genuine participation, you taint the outcome. The results are effectively meaningless (Evan, 2012).

Unlike individual social networkers, these entities actively use the social media for advertising and marketing. While commercial messages and interactions with consumers cocllaborate with media, events, entertainment, retailers, and digital services by social media, intergrated marketing activities can be carried out with far less effort and cost than previously (Kim \& Ko, 2012).

\section{Material and Methodology}

This research employs a qualitative descriptive in the form of in-depth interviews and content analysis. This research aims at describing, explaining, and analyzing phenomena completed with proofs from various sources which have been narrated in scientific form (Kriyantono, 2014).

Qualitative research does not focus on the size of population or sampling, on the contrary, the population or the sampling is very limited. If the data collected is sufficient and able to describe the inspected phenomena, it is not necessary to look for other sampling. It is more focus on the quality of the data, not the quantity (Pratiwi \& Andarini, 2020).

Qualitative approach is conducted through in-depth interviews on two interviewees as main data resources. Informant 1 and informant 2 are both housewives who help develop YLEO business and have status as "silver leaders". In this research, the informer selection technique employs purposive sampling.

The criteria of the informers are in accordance with the aims of this research, those are: (1) YLEO product's consumer; (2) business builder category member; and (3) actively using social media. While secondary data is used for additional information, those are YLEO official website and all YLEO social media platforms. Both main and additional data sources are used to get results of quality (Sarah, 2016).

The writer does not mention the name of the company implicitly nor enclose evidence in the form of photos of social media activities due to not yet receiving response related to journal writing. Thus, the method used is content analysis and supported by two interviewees (member business builder) who agree to become the informers.

\section{Result and Discussion}

According to Evan (2012), social media marketing activities can be measured by four dimensions those are collaborative, participation, applied knowledge transfer, and social activity (Sarah, 2016). By these four dimensions, we are going to classify and see various activities done by "Silver Leader" and YLEO through social media.

As the top stage in engagement process, which can be proven by measuring the linkages between customers and the company. Engagement is the key in utilizing social media and creating a social business which puts forward collaboration than exposure and impression (Sarah, 2016).

There are many collaborative activities created by YLEO through their social media, such as Instagram Photo Contest \#BeImpactfulWithYLID specifically for members who take part in offline training "Effective Strategies Workshop for Impactful 
and Bold Product Sharing" by Jen O'Sullivan and Alvin Adam. Jen O'Sullivan is YLEO member since 2007 who comes from Southern California, and Alvin Adam is known as a presenter, news anchor, actor, as well as the owner of Alvin Adam Public Speaking and Communication School.

Collaborative steps taken by YLEO are not only giving education and widening networks but also helping members to improve their communication abilities. Communication ability becomes a very important thing in doing both marketing activities and product sharing. This photo contest program is followed by 43 followers who participate in live offline training mentioned above. This information is also gained from Informant 1 who is a "Silver Leader" saying that there are many collaborations created:

"... these are only some examples of the collaborations. The collaborations usually discuss the benefits of oils for life and how to run a business well..."

As stated by Evan (2012) in his book, collaboration occurs when there are satisfaction and certain values created from transaction result between members of community, between employees, also between company and their colleagues which happen repeatedly (Sarah, 2016).

Next, other collaborative activity is by utilizing Zoom platform and Live Instagram in various events. Informant 1 says that the event is held routinely every three days some of those are such as (1) Favor Oil Instagram Live Collab themed "Pandemic and Our Children" by Mamikos Anita and Jill Van Diest; (2) Virtual Office Tour by Indri Melanie as the training assistant manager and Maharani Yoga as a member service team leader which discuss about tips and tricks to optimize VO for economic growth; (3) Collaboration with Koen Verheyen, as the board of commissioners of APLI as well as the company's direct selling consultant, who discuss about company's direct selling legitimacy in Indonesia, the success of a business owner in direct selling industry, and the future of direct selling business in Indonesia; and (4) Collaboration with Niko Julius, an Instagram expert, themed "New Year, New Opportunity Part 1- Instagram Content Marketing" who speaks about the right strategy in content optimization on Instagram and Instagram Story. This is strengthened by the statement from Informer 1 who says that every YLEO membership has opportunity to help build YLEO business. Having creating collaborations, it can help "newbies" in doing direct selling businesses.

Next, YLEO Indonesia's another social activity is donating 1000 Alat Pelindung Diri $(A P D)$ for some hospitals. The reason is for humanity without expecting profit. Another collaboration activity routinely held by YLEO is an offline interactive talk-show themed "LYPR: Live Your Passion Rally". This event is held worldwide simultaneously every three months. This event can take venue anywhere, such as home, café, office, and so on. The aim of the event is for sharing while inviting members or potential members to learn things from introducing YLEO, DIY Class, Baby Oilmassage Class, and so on. However, due to government regulations which impose us on applying $P S B B$ (social distancing) program, it makes the LYPR event held virtually.

\section{Participation}

According to Evan (2012), participation is an indicator which can be collected by existing measure, that is creating content, accuracy, number of reviews, comments and postings which then can be used to assess the level of interest on overall activity level in online community (Sarah, 2016).The measure on participation dimension can be seen by the number of websites accessed. Every member who wants to buy YLEO product can access its website or from business builder members who then help customers do the purchase on the website. The result shows that YLEO website's visitor is very good

While participation on YLEO social media can be seen through the received feedback for every content posted or shared every day, both on social media Instagram, Facebook, TikTok, and WhatsApp, both commercially and noncommercially. However, the mostly used social media are Instagram and WhatsApp. Informant 1 and Informant 2 say that commercial contents are usually in the form of product photos and discounts. While the non-commercial ones are tutorial videos cleaning diffusers, Do It Yourself (DIY) mix and match oil, information about tips on using the oil which can be mixed with drinks and for beauty mask, and many more. According to Informant 1 and Informant 2 , the sharing mechanism on social media is at least once a day, starting at 8.00 in the morning. Usually, the received feedbacks are in the form of comments, likes, and also mentions from consumers who use on-the-market YLEO products. Informer 1 herself, every day receives 
various feedbacks, from consumer asking about the product or the price to those who buy the product.

"...50\% of those who buy watch Instagram Story or WhatsApp. There must be someone who buys even only one person..."

Based on data analysis result, the most liked content by the followers are the information about oil application and the oil product itself. Every contents are always informatively visualized and attracting attention in photos and captions so that every marketers can subtly attract people's interests on YLEO products.

\section{Applied Knowledge Transfer}

According to Evan (2012), is a basis to evaluate knowledge and given solution by ranking the contents created based on received feedbacks and may be mostly re-shared by other users. The content on the top of the list is the most useful or the most of value (Sarah, 2016). The activities done in this dimension is giving informative content on both commercial and non-commercial ones. The information in the commercial content is usually in "Live Your Passion" contents which contain product information described in various themes in order to attract followers to feel the benefit of the oil themselves. While for the noncommercial contents, they are usually conveyed through education about tips on how to make good oil mixture for health and beauty, DIY making mask and facial wash, tips on how to treat diffusers, washing fruits and vegetables, and many others. Through the dimension of applied knowledge transfer, YLEO expects their followers understand the benefits of YLEO not only for health and fragrance but also so many benefits gained by the consumers using YLEO products. In accordance with the definition of applied knowledge transfer which defines that participation and collaboration happen in social media activities enable the occurrence of applied knowledge transfer, whereas the key to measure the value of participation is to collectively ensure that that participation is corresponding to the business target and it happens (Evan, 2012).

\section{Social Activities}

The dimension can be done by browsing the number of connections, friends or followers who are connected and the numbers of mutual friendships or other connections if any (Sarah,
2016). YLEO Instagram account is officially verified by the Instagram. The number of YLEO Instagram account followers is 150,000 and 10,000 on Facebook per 31 January 2021 and increases every day. Per 9 March 2021 the number of followers on Instagram reaches 161,000 and 12,578 on Facebook. Then the number of contents, as one way to see how active a social media account is. The number of contents posted by YLEO Instagram account is at least one content every day, in relevance with the statement from Informant 1 and 2. "...the content posted on Instagram or WhatsApp is at least one every day."

Based on the increasing number of followers as many as 11,000 on Instagram and 2,578 on Facebook in a short time shows that YLEO Instagram account's social activity is very good. This is also related to the number of communications intertwined between followers and YLEO in the form of collaborations, interactive talk shows and webinars every day showing the importance of connections in everyday social media activities.

\section{Conclusion}

The management of social media nowadays has become the most important part for every company. This is relevance to the fact that people's consumption on "new media" in Indonesia is very large. This research aims at understanding how YLEO utilizing social media to support their business activity through marketing social media. The application of marketing social media done by YLEO is already maximal in relevance with marketing social media dimensions.

Activities in utilizing marketing social media by creating attractive contents create connection or audience involvement in various activities. Moreover, through social media activity indirectly encourage interaction with audience, so that we are able to further know and understand the expectation and the relevancy of the messages conveyed to the audience.

\section{References}

Abidin Achmad, Z., Zendo Azhari, T., Naufal Esfandiar, W., Nuryaningrum, N., Farah Dhilah Syifana, A., \& Cahyaningrum, I. (2020). Pemanfaatan Media Sosial dalam Pemasaran Produk UMKM di Kelurahan Sidokumpul, Kabupaten Gresik. Jurnal Ilmu Komunikasi, 10(1), 17-31. https://doi.org/10.15642/jik.2020.10.1.1731 
APJII. (2020). Laporan Survei Internet APJII 2019 - 2020. Asosiasi Penyelenggara Jasa Internet Indonesia, 2020, 1-146. https://apjii.or.id/survei

Aryanto, A. (2020). Di Tengah COVID-19, Pemasaran Online dan Digital Branding Jadi Pilihan. Wartaekonomi.

Badan Pusat Statistik. (2020). Pertumbuhan Ekonomi Indonesia Triwulan IV-2019. Www.Bps.Go.Id, 17/02/Th. XXIV, 1-12. https://www.bps.go.id/pressrelease/2020/0 2/05/1755/ekonomi-indonesia-2019tumbuh-5-02-persen.html

Boon-Long, S., \& Wongsurawat, W. (2015). Social media marketing evaluation using social network comments as an indicator for identifying consumer purchasing decision effectiveness. Journal of Direct, Data and Digital Marketing Practice, 17(2), 130-149. https://doi.org/10.1057/dddmp.2015.51

Budiatmo, A., \& Kurniasari, M. (2018). Pengaruh Social Media Marketing, Brand Awareness Terhadap Keputusan Pembelian Dengan Minat Beli Sebagai Variabel Intervening Pada J.Co Donuts \& Coffee Semarang. Jurnal Administrasi Bisnis, 7(1), 25-31. https://ejournal.undip.ac.id/index.php/jani s/article/view/22571

Christiastuti, N. (2020). PBB: Pandemi Virus Corona Krisis Global Terburuk Sejak Perang Dunia II. News.Detik.Com. https://news.detik.com/internasional/d4960642/pbb-pandemi-virus-coronakrisis-global-terburuk-sejak-perangdunia-ii

CNN Indonesia. (2020). Daftar Perusahaan Global yang Bakal Bangkrut karena Corona.

https://www.cnnindonesia.com/ekonomi/2 0200714152645-92-524535/daftarperusahaan-global-yang-bakal-bangkrutkarena-corona

Evan, D. (2012). Advance Praise for Social Media Marketing: An Hour a Day, Second Edition.

Felix, R., Rauschnabel, P. A., \& Hinsch, C. (2017). Elements of strategic social media marketing: A holistic framework. Journal of Business Research, 70, 118-126. https://doi.org/10.1016/j.jbusres.2016.05. 001

Ghoshal, Dr. M. (2019). Social Media as an Effective Tool to Promote Business- An Empirical Study. Global Journal of
Management and Business Research: E Marketing, 19(1), 15-25.

Hidayat, D., Anisti, Purwadhi, \& Wibawa, D. (2020). Crisis management and communication experience in education during the covid - 19 pandemic in indonesia. Jurnal Komunikasi: Malaysian Journal of Communication, 36(3), 67-82. https://doi.org/10.17576/JKMJC-20203603-05

Kim, A. J., \& Ko, E. (2012). Do social media marketing activities enhance customer equity? An empirical study of luxury fashion brand. Journal of Business Research, 65(10), 1480-1486. https://doi.org/10.1016/j.jbusres.2011.10. 014

Kriyantono, R. (2014). Teknik Praktik Riset Komunikasi Disertai Contoh Praktis Riset Media, Public Relations, Advertising, Komunikasi Organisasi, Komunikasi Pemasaran. Kencana Prenadameida Group.

Laksamana, A. (2020). Adapt or Die (W. N. Cahyo, Ed.). Orbit Indonesia.

Lubis, M. (2020). Digital Consumers Show Positive Growth Trends - Nielsen. Nielsen Company Indonesia. https://www.nielsen.com/id/en/pressreleases/2020/digital-consumers-showpositive-growth-trends/

Mangold, W. G., \& Faulds, D. J. (2009). Social media: The new hybrid element of the promotion mix. Business Horizons, 52(4), 357-365.

https://doi.org/10.1016/j.bushor.2009.03.0 02

Meilinda, N. (2018). Social Media on Campus : The Journal of Society \& Media, 2(1), 5364.

Mukherjee, K. (2019). Social media marketing and customers' passion for brands. Marketing Intelligence and Planning, 38(4), 509-522. https://doi.org/10.1108/MIP-10-20180440

Papasolomou, I., \& Melanthiou, Y. (2012). Social Media: Marketing Public Relations' New Best Friend. Journal of Promotion Management, 18(3), 319-328. https://doi.org/10.1080/10496491.2012.69 6458

Patma, T. S., Wardana, L. W., Wibowo, A., \& Narmaditya, B. S. (2020). The Shifting of Business Activities during the COVID-19 Pandemic: Does Social Media Marketing Matter? The Journal of Asian Finance, 
Economics and Business, 7(12), 283-292. https://doi.org/10.13106/jafeb.2020.vol7.n o12.283

Pratiwi, M., \& Andarini, R. S. (2020). Adaptasi Muslim Milenial Dalam Perjalanan Wisata Halal Di Negara Non-Muslim. Mediakom: Jurnal Ilmu Komunikasi, 4(1), 46-61. https://doi.org/10.35760/mkm.2020.v4i1.2 495

Prayoga, K. (2020). How jokowi communicates with the public during COVID-19 crisis: An analysis of tweets on twitter. Jurnal Komunikasi: Malaysian Journal of Communication, 36(2), 434-456. https://doi.org/10.17576/JKMJC-20203602-26

Presiden Republik Indonesia. (2019). Peraturan Pemerintah Republik Indonesia Nomor 21 Tahun 2020 (p. 8). SK No 022868.

Rochadi, D. (2016). Pemanfaatan Media Sosial Sebagai Strategi Public Relations Dalam Manajemen Krisis Konser Lady Gaga.

Sarah, S. (2016). Analisis Aktivitas Sosial Media Marketing Hijup Melalui Instagram Sebagai Salah Satu Strategi Marketing.

Solis, B. (2011). Engage!: the complete guide for brands and businesses to build, cultivate, and measure success in the new web. John Wiley \& Sons, Inc., Hoboken, New Jersey.

South, J. (2011). The Power of Real-time Social Media Marketing. In Journalism Studies (Vol. 12, Issue 5).

undaram, R., Sharma, R., Shakya, A. (2020). Power of digital marketing in building brands: A review of social media advertisement. International Journal of Management, 11(4), 244-254. https://doi.org/10.34218/IJM.11.4.2020.0 $\underline{25}$

We Are Social \& Hootsuite. (2020). Indonesia Digital report 2020. Global Digital Insights, 247. https://datareportal.com/reports/digital2020-global-digital-overview

Young Living. (2018). About Young Living Essential Oils. Youngliving.Com.

Zaitseva, E. A., Srednyak, K. v., \& Kudryavtseva, M. E. (2019). SMM-tools in the Promotion of Small and MediumSized Business (In the Case of Nizhny Novgorod Market). Proceedings of the 2019 IEEE Communication Strategies in Digital Society Seminar, ComSDS 2019, 93-95.
https://doi.org/10.1109/COMSDS.2019.8 709644 